\title{
200 ÉVE SZÜLETETT KRUSPÉR ISTVÁN
}

\section{ISTVÁN KRUSPÉR WAS BORN 200 YEARS AGO}

\author{
Ádám József \\ az MTA rendes tagja \\ Budapesti Műszaki és Gazdaságtudományi Egyetem Általános- és Felsőgeodézia Tanszék \\ jadam@epito.bme.hu
}

\begin{abstract}
ÖSSZEFOGLALÁS
Kruspér István a geodézia első magyarországi tudományos művelője. Elméleti és gyakorlati munkássága a geodézia és a metrológia területén egyaránt jelentős, és a műszaki felsőoktatás kiemelkedő művelője is volt. Meghatározó szerepet játszott a méterrendszer hazai és nemzetközi bevezetésében. A modern magyar mérésügy egyik megteremtőjeként tartjuk számon. A cikk áttekinti Kruspér István szakmai-tudományos tevékenységének főbb eredményeit.
\end{abstract}

\section{ABSTRACT}

István Kruspér was the first Hungarian scientist in the field of geodesy, and an outstanding personality of the technical higher education in Hungary. Both his theoretical and practical activities in the field of geodesy and metrology are considerable. His role was definitive and significant in introducing the metric system in Hungary. This article reviews the main achievements of István Kruspér's professional and scientific activities.

Kulcsszavak: etalon, földméréstan, geodézia, komparátor, mértékegység, méterrendszer, metrológia

Keywords: etalon, surveying, geodesy, comparator, standardized units, metric system, metrology

Kruspér István 1818. január 25-én született Miskolcon, ahol iskoláit is végezte, majd joghallgató lett Késmárkon. Jogi tanulmányait félbehagyva 1836-ban Löcsén egy mérnök mellett gyakornoki funkciókat látott el. 1841 és 1844 között a bécsi politechnikai intézetben (a mai Bécsi Mủszaki Egyetem elődje) végezte egyetemi tanulmányait. Végzés után ugyanitt 1844-től 1847-ig Simon Stampfer, a geodézia (gyakorlati mértan) professzora mellett tanársegédként dolgozott. 1847 
októberében Bécsben optikai, látszerészeti és finommechanikai műhelyt nyitott, és szemüvegek, valamint látszerészeti eszközök árusításába fogott. Közben nyugat-európai tanulmányutakon vett részt, amelyek során megalapozta elméleti és gyakorlati tudását.

1850-ben meghívták a pesti József Ipartanoda - a mai Budapesti Müszaki és Gazdaságtudományi Egyetem (BME) elődje - tanárának. Az első évben az elemi mennyiségtant és mértant oktatta, majd 1851 és 1867 között a gyakorlati mértan és a mechanikai technológia tanára volt. Ezek mellett (helyettesként) 1851-1857 között a felsőbb mennyiségtant, 1863-1864-ben pedig a géptant, a mechanikát és a szerkezettant is tanította. Az Ipartanoda Mủegyetemmé (BME) fejlesztésével 1867-ben a geodézia tanára lett, és ezután már csak ezzel a tárggyal foglalkozott nyugállományba vonulásáig, 1894-ig. Tanszékvezetése alatt a geodéziai mérőgyakorlatokat Visegrádon tartották, négynapos terepgyakorlatokon. 1871 és 1874 között a mérnöki és építészeti osztály dékánja volt. Egyetemi tanárként kiváló pedagógus volt. Tanítványai szerették és tisztelték. A 2002-ben fennállásának 225. évfordulóját ünneplő, BME Általános- és Felsőgeodézia Tanszéket (az egykori tanszékének mai jogutódja) ő vezette a leghosszabb ideig, 1851-től 1894-ig (Ádám-Homolya, 2002).

Az 1860-as évek végére Kruspér István már jelentős szakmai tekintélyt szerzett. 1869 és 1871 között az általa elkészített tervek alapján, személyes felügyelete mellett végezték Pest város geodéziai felmérését. Rábízták Buda 1872 és 1875 között elvégzett felmérésének, valamint Szeged város háromszögelésének és szintezésének felülvizsgálatát is.

Kruspér tanári - és egyben szakmai - munkásságának fontos eleme az 1868ban (változatlan utánnyomásban 1869-ben) megjelent, Földmértan. Kézikönyv, erdőszeti és müegyetemi más rokon intézetek elöadásaira és mérnöki használatra, különös tekintettel hazai viszonyainkra címü könyve. A müvet az MTA 1870-ben Akadémiai Nagydíjjal tüntette ki, és 400 arannyal jutalmazta. Nyomtatott formában ez az első magyar nyelvü geodéziai kézikönyv, amelyről Arany János, az MTA akkori főtitkára vonatkozó jelentésében a következőket írta: ,... a gyakorlati mértant kimerítőleg tárgyalja; irodalmunkban úttörő; nemcsak a tudomány színvonalán áll, hanem azt sok részben előbbre viszi, gyakorlati haszna jelentékeny és nagyon élénken érzett hézagot tölt ki” (Keresztury, 1964, 405.). A mü kéziratának lektorálására egyébként Arany János Szabó József geológus akadémikust kérte fel. A kézikönyv második kiadásban 1885-ben jelent meg, amely felsőgeodéziai résszel bővült, mert az 1871/1872-es tanévtől már ez is szerepelt a tananyagban. Kruspér e kiadásban tekintettel volt az időközben bevezetett méterrendszerre is.

Kruspér Istvánt 1867-ben a méterrendszer hazai bevezetésével foglalkozó munkabizottság vezetésével bízták meg az MTA keretében (Verő, 1976). Az akadémiai bizottság többek között azt javasolta, hogy a mértékegységek nevét ne fordítsák le magyarra, maradjon azok neve méter és kilogramm, továbbá a 


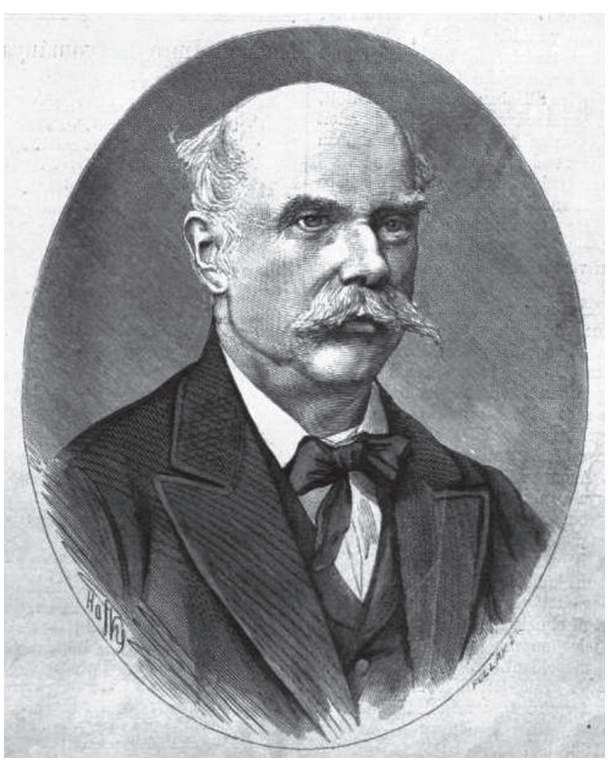

Kruspér István portréja

a Vasárnapi Ujság 1876, 2. számában

(Wikipédia)

szabványos alapmérték a Nagy Károly csillagász akadémikus által korábban (1844) vásárolt, platinából készített méter- és kilogrammetalon legyen.

Kruspér István a magyar kormány megbízásából Szily Kálmán akadémikussal együtt vitte ki Párizsba az MTA birtokában lévő, majd 1870 januárjában az állam tulajdonába került, Nagy Károly-féle méter- és kilogrammetalont komparálás céljából, és francia szakértői bizottság közremúködésével végezték el az összehasonlítást a párizsi ösetalonokkal (métre et kilogramme des Archives) 1870 áprilisában. Ekkor Kruspér egy hibát is felfedezett a francia komparátoron (Kruspér, 1873). Az összehasonlító mérések eredményének birtokában törvényjavaslat készült, amelynek előkészítésében Kruspér István meghatározó szerepet játszott.

A méterrendszer használatát elrendelő törvény szövegezésében személyesen is részt vett. A törvényjavaslatot 1874 . április 20 -án VIII. törvénycikk jelzéssel törvényerőre emelték. Ettől az időponttól kezdve (a nemzetközi méteregyezmény aláirása előtt már egy évvel) Magyarországon a méter és a kilogramm az egyedül és kizárólagosan törvényes mértékegységek.

Kruspér István a Mủegyetem ajánlása alapján szintén Szily Kálmán akadémikussal együtt képviselte Magyarországot a párizsi méterértekezleten 1870-1874 között, amelynek keretében aktív részvételt vállalt a nemzetközi méteregyezmény (Convention du Métre) elökészítésében. A többször összeült méterértekezlet célja lényegében az volt, hogy a méter általános elfogadását ajánlja minden államnak, és javaslatot kellett tennie olyan nemzetközi szervezet létrehozására, amely a méterrendszer világméretü elterjesztését intézi. (A javaslat szerint 1875-ben életre hívott szervezetek eredeti hármas tagozódásban ma is fennállnak és müködnek.) Kruspér István már az 1870. augusztusi méterértekezletről és a korábbi kapcsolódó tudományos tevékenységéről az 1871. február 13-án tartott akadémiai rendes tagsági székfoglaló előadásában számolt be (Kruspér, 1871). Kruspér diplomáciai sikert is aratott, mert az osztrák küldött akarata ellenére el tudta érni, hogy Magyarországot mint önálló államot vegyék figyelembe, és külön szavazati jogot kapjon (Regőczi, 1968). A Nagy Károly-féle etalonok párizsi ellenőrzése és a méterértekezlet keretében kifejtett kiváló szakmai munkájának elismeréséül egy 
1872-es évszámmal ellátott, szép, tengerkék, aranyozott sévres-i porcelánváza őrzi nevét és a párizsi értekezlet emlékét, amelyet családja a Magyar Nemzeti Múzeumnak ajándékozott.

Kruspér Istvánnak a metrológia területén kifejtett eredményes tevékenysége nemzetközi elismertségét jelzi az, hogy beválasztották a Nemzetközi Súly- és Mértékügyi Bizottságba (Comité internationale des poids et mesures, CIPM). Ezt a tisztséget tizenöt éven át töltötte be, 1879 és 1894 között. A szervezetnek Kruspér idejében tizenkét, jelenleg tizennyolc állandó tagja van. Munkásságával nagyban hozzájárult a magyarországi mérésügy intézményi hátterének megszervezéshez is, mert kezdeményezése és előterjesztése alapján állította fel a magyar kormány a Magyar Királyi Mértékhitelesítő Bizottságot, a későbbi Országos Mérésügyi Hivatal $(\mathrm{OMH})$ elődjét, amelynek első vezetője volt 1878-1894 között. Magyarország 1889-ben megkapta a 14. sorszámú méter- és a 16. sorszámú kilogrammetalont, amelyeket az 1891. évi VI. törvénycikk értelmében a Nagy Károly-féle etalonok helyett törvényes alapmértékeknek tekintettek (a 16. sorszámú kilogrammetalon még ma is a törvényes alapmérték Magyarországon) (Ádám, 2017). A megszerzett etalonok vizsgálatához Kruspér István új, korszerủ müszereket szerkesztett.

Oktatói tevékenysége és a geodézia (földmérés és térképészet) már akkoriban is gyorsan fejlődő szakanyagának rendszerező leírása, továbbá metrológiai vizsgálatai mellett Kruspér jelentős müszertervezöi munkásságot is magáénak mondhatott: a geodéziai mérőmüszerek, különösen a szintezők egyes elemeinek módosításával, valamint távmérőműszerek fejlesztésével járult hozzá a földmérő mérnökök müszertárának gyarapításához. A müszertant gazdagították az optika tárgykörében folytatott elméleti kutatásai is. Új szintező müszert (akkori nevén „lejtméröt”) is tervezett, amelyet Németországban gyártottak. Az etalonok vizsgálatához több új müszert szerkesztett, más müszereken javításokat hajtott végre. Műszereivel az 1878-as párizsi kiállításon ezüst-, az 1885. évi brüsszeli kiállításon pedig aranyérmet nyert. Több geodéziai müszer konstrukcióját Budapesten a Bosnyák téri geodéziai székházban állították ki.

Kruspér István szakmai és oktatói-tudományos elfoglaltsága mellett sokat tett a magyar geodézia társadalmi úton történő támogatására is. Részt vett a Magyar Mérnök Egylet (későbbi nevén a Magyar Mérnök és Építész Egylet, MMÉE) alapításában (1866), amelynek elnökhelyettese is volt. Ö volt az egylet geodéziai („földmérészeti”) szakosztályának az első elnöke (1867-1881). 1867-től 1884-ig mủködött az MMÉE Közlönyének szerkesztőbizottságában, 1868-ban ő szerkesztette a Közlönyt.

Kruspér István kiemelkedően gazdag szakmai-tudományos munkásságát számos kitüntetéssel ismerték el. Az MTA a szabadságharc utáni első tagválasztó ülésén, 1858-ban levelező tagjává, 1870-ben rendes tagjává, 1899-ben pedig tiszteletbeli tagjává választotta. A Francia Tudományos Akadémia is tagjai sorába 
választotta 1872-ben. Megkapta a Vaskorona-rendet (1885) és a Lipót-rend lovagkeresztjét (1894), a szerb Trakova-rendet (1884) és a francia Becsületrend tiszti keresztjét (1894) is.

Tiszteletére a Müszaki és Természettudományi Egyesületek Szövetségének (MTESZ) Méréstechnikai és Automatizálási Tudományos Egyesülete (MATE) 1956-ban Kruspér István-emlékérmet alapított a kiemelkedő társadalmi és tudományos tevékenység, a MATE szaklapjában megjelent, jelentős tudományos eredményt ismertető cikkek jutalmazására.

Emlékének megőrzése céljából a BME Központi épületének aulájában áll mellszobra, a magasföldszint 20-21. számú elöadótermet róla nevezték el; ez a Kruspér-terem, amely egykori tanszéke mai jogutódja, a BME Általános- és Felsőgeodézia Tanszéke mellett található. Emlékét a Fiumei úti temetőben található síremlék őrzi. Fővárosunk 1907-ben a Múegyetem közelében utcát nevezett el róla.

\section{IRODALOM}

Ádám J. (2017): Az egységes mértékegységrendszer kialakitása és hazai bevezetésének akadémiai vonatkozásai. Előadás az MTA X., Földtudományok Osztályának ülésén, MTA, Budapest, 2017. október 17.

Ádám J. - Homolya A. (2002): A Tanszék története és működése alapításától napjainkig. Geodézia és Kartográfia, 54, 10, 4-12. https://docplayer.hu/2864338-A-tanszek-tortenete-es-mukodese-alapitasatol-napjainkig.html

Keresztury D. (szerk.) (1964): Arany János összes müvei. XIV. köt.: Hivatali iratok 2. Akadémiai évek (1859-77). Budapest: Akadémiai Kiadó

Kruspér I. (1871): A párisi meter-prototyp az 1870. augusztusi méter-értekezleten. Értekezések a math. és term. tud. köréböl, Pest, http://real-eod.mtak.hu/1632/

Kruspér I. (1873): A párisi levéltári méterrúd véglapjain levő mélyedések megméréséröl. Budapest, http://real-eod.mtak.hu/1670/

Regőczi E. (1968): Kruspér István emlékezete. Geodézia és Kartográfia, 20, 2, 81-86.

Verő J. (1976): Akadémiánk és a méter-rendszer bevezetése. Magyar Tudomány, 2. http://members.iif.hu/visontay/ponticulus/rovatok/limes/meter.html 